\title{
Morphology and ultrastructure of the male reproductive system of the woolly beech aphid Phyllaphis fagi (Hemiptera: Aphididae: Phyllaphidinae)
}

\author{
KARINA WIECZOREK ${ }^{1}$ and Piotr ŚWIĄTEK ${ }^{2}$
}

\begin{abstract}
${ }^{1}$ Department of Zoology, ${ }^{2}$ Department of Histology and Embryology of Animals, Faculty of Biology and Environmental Protection, University of Silesia, Bankowa 9, 40-007 Katowice, Poland; e-mails: karina.wieczorek@us.edu.pl; piotr.swiatek@us.edu.pl
\end{abstract}

Key words. Aphididae, Phyllaphidinae, Phyllaphis fagi, male reproductive system, ultrastructure

\begin{abstract}
In the present paper we describe for the first time the ultrastructure of the male reproductive system of aphids using Phyllaphis fagi as a representative. Paired testes of this species consist of three follicles each, arranged in a rosette, the walls of the proximal part of vasa deferentia cling together, accessory glands are club-shaped and elongated whereas the ejaculatory duct is reduced. Our study also shows that vasa deferentia, accessory glands and ejaculatory duct are histologically very simple. All of them are composed of cubical epithelium of secretory type. The epithelial cells are rich in rough endoplasmic reticulum, Golgi complexes and produce small heterogeneous vacuoles. The apical membrane of these cells forms microvilli. The reproductive system epithelia stand on thin basal lamina. Outside the basal lamina thin muscle fibres are observed. Histochemical staining shows that secretion filling the lumen of vasa deferentia and accessory glands contains proteins and polysaccharides.
\end{abstract}

\section{INTRODUCTION}

Phyllaphidinae are a small group of aphids comprising four genera and about 13 species associated mainly with Fagaceae and Lauraceae (Remaudière \& Remaudière, 1997). Stegophylla Oestlund, 1922 is a Nearctic genus, Phyllaphis Koch, 1856 and Diphyllaphis Takahashi, 1960 are holarctic genera, whereas Machilaphis Takahashi, 1960 is an Oriental genus (Blackman \& Eastop, 1994). On the basis of morphological characters a new range for this subfamily was proposed by Quednau \& Remaudière (1994).

The woolly beech aphid Phyllaphis fagi Linnaeus, 1767 , the best recognized representative of the subfamily Phyllaphidinae, is a monoecious and holocyclic species distributed in the Palaearctic and introduced to North America, Australia and New Zealand (Blackman \& Eastop, 1994). P. fagi is well-studied morphologically and ecologically (Stroyan, 1977; Heie, 1982; Nieto Nafria \& Mier Durante, 1998); it is a serious pest of beech trees Fagus silvatica L. (Iversen \& Harding, 2007a, b). On the other hand, data concerning the internal anatomic structure of this species, especially the structure of the reproductive system, are incomplete. Only Wieczorek \& Światek (2007) give a short description of the morphology of the male reproductive system. The ultrastructure of this system in aphids, including $P$. fagi, has never been studied before.

The life cycle of the examined species consists of seven yearly generations. At the end of May winter eggs hatch producing the first virginoparous generation - fundatrices (F1). Next virginoparous generations (F2-F5) - virgines, are winged or wingless, and live on the underside of leaves of $F$. silvatica until the end of August. In September females of the sixth virginoparous generation sexuparae (F6) produce sexuales - wingless, oviparous females and winged males (F7), which are observed until the end of October. After mating, oviparous females lay fertilized eggs that overwinter (Prabucki, 1972).

Our poor knowledge on the male reproductive system of this species results from the rarity of males. However, earlier research on the morphology of the male reproductive system of aphids (Klimaszewski et al., 1973; Głowacka et al., 1974; Wieczorek \& Wojciechowski, 2004; Wieczorek, 2006), including such characters as the number of testis follicles, the connection of follicles and vasa deferentia, the position of the proximal part of vasa deferentia as well as the development of accessory glands and the ejaculatory duct, show that these structures are a source of data helpful in shaping views on the classification of aphids. Also histological analysis and ultrastructure of the studied system can be a source of relevant information and useful in the taxonomy of aphids.

\section{MATERIAL AND METHODS}

\section{Insects}

Adult males of $P$. fagi were collected from the underside of leaves of F. silvatica in October 2006 and 2007 in Katowice, Poland.

\section{Light and electron microscopy}

The material was treated with Carnoy solution for 20-30 min. and transferred to $70 \%$ ethyl alcohol. For a plane reconstruction of the reproductive system the paraffin method was applied (Wieczorek, 2006). Several complete series of microtome slides (longitudinal sections and cross-sections) were prepared, as well as the male reproductive system dissected from whole insects (total preparation).

For a histological analysis, specimens were dissected and body fragments with the reproductive system fixed in $2.5 \%$ glutaraldehyde in $0.1 \mathrm{M}$ phosphate buffer ( $\mathrm{pH} 7.4$ ) at room temperature for several days and, after washing in phosphate buffer, postfixed for $1 \mathrm{~h}$ in $1 \%$ osmium tetroxide $\left(\mathrm{OsO}_{4}\right)$ in the same 

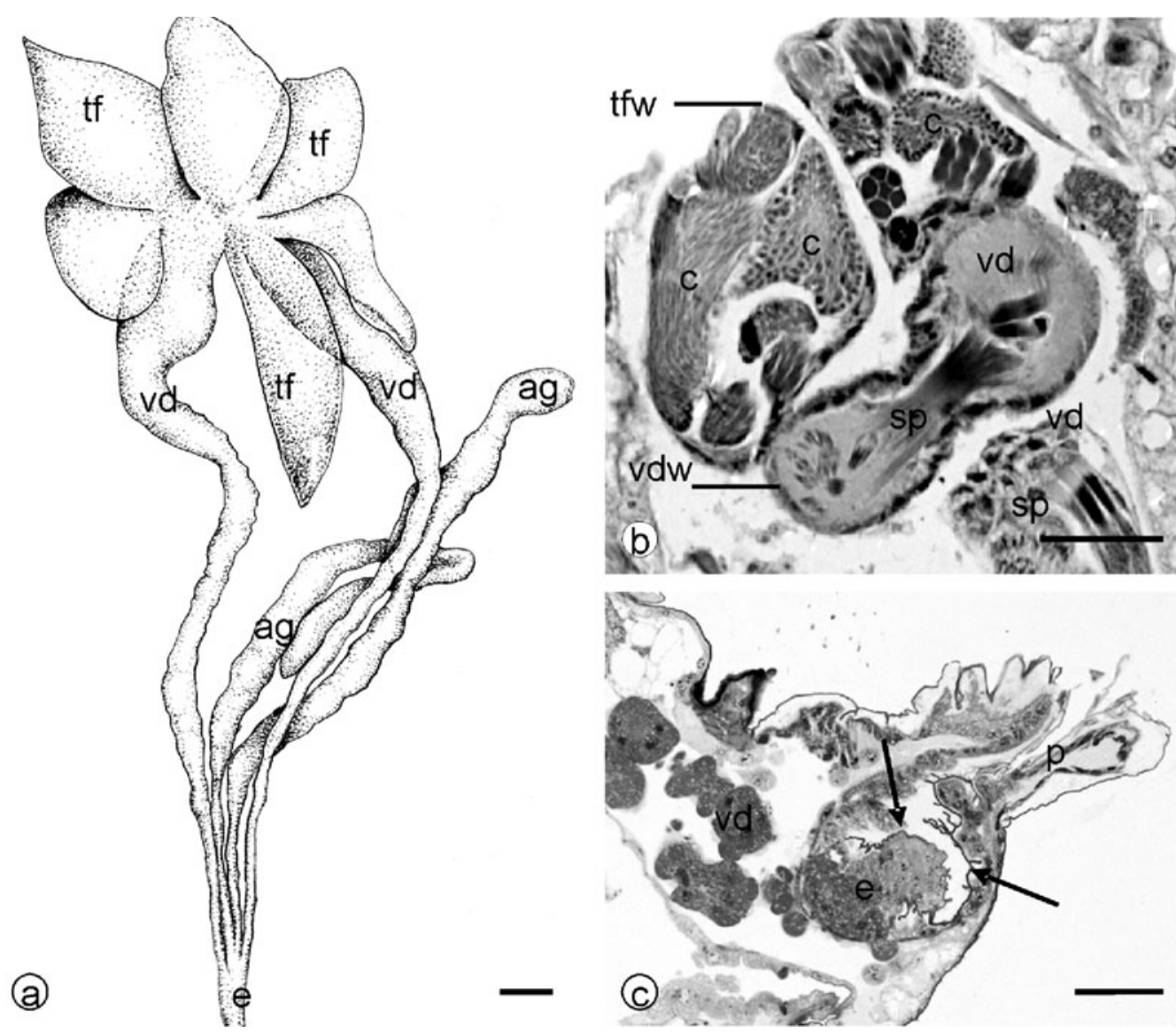

Fig. 1. General morphology of the male reproductive system of Phyllaphis fagi. a - line drawing; $\mathrm{b}$ - paraffin section; $\mathrm{c}-$ epon semi-thin section. ag - accessory gland; $\mathrm{c}$ - cysts with developing sperm; e - ejaculatory duct; $\mathrm{p}$ - penis; sp - spermatozoa; tf - testicular follicles; tfw - testicular follicle wall; vd - vasa deferentia; vdw - vas deferens wall. Arrows mark cuticle of the ejaculatory duct. Light microscopy (LM), bars $=50 \mu \mathrm{m}$.

buffer, dehydrated in a graded series of ethanol and acetone and then embedded in Epon 812 (Fullam Inc., Latham, NY, USA). $0.7 \mu \mathrm{m}$ thick sections were stained with methylene blue and additionally stained using the PAS method to localize polysaccharides, bromophenol blue (BPB) for polypeptides, and Sudan black B for lipids. Semi-thin sections were examined with an Olympus BX60 microscope equipped with a DP12 digital camera and the AnaliSIS 3.2 (Soft Imaging System) software. Ultra-thin sections $(70-80 \mathrm{~nm})$ were cut on a Leica ultracut UCT ultramicrotome. After staining with uranyl acetate and lead citrate, sections were examined in a Hitachi H500 electron microscope at $75 \mathrm{kV}$.

\section{RESULTS}

\section{General morphology of the male reproductive system of $P$. fagi}

The male reproductive system of $P$. fagi runs parallel to the longitudinal body axis. Testes holding three follicles each lie in the central part of the abdomen. Lobate follicles (109-241 $\mu \mathrm{m}$ long and 62-109 $\mu \mathrm{m}$ wide, $\mathrm{n}=36$ ) are arranged in a rosette and overlap (Fig. 1a). Vasa deferentia run separately and are expanded $(78-93 \mu \mathrm{m})$ in $1 / 3$ of their length $(546-624 \mu \mathrm{m}, \mathrm{n}=12)$. In the proximal part their walls cling together (Fig. 1b). Accessory glands are club-shaped and elongated (585-702 $\mu \mathrm{m}, \mathrm{n}=12)$; the ejaculatory duct is reduced (Fig. 1c).

\section{Ultrastructure}

\section{Testicular follicle}

Each testicular follicle contains several cysts with developing male germ cells (Fig. $2 \mathrm{a}-\mathrm{d}$ ). Since a detailed description of spermatogenesis in $P$. fagi is not the aim of present study, only some general remarks will be made. In testicular follicles of adult males only germ cells in advanced stages of spermatogenesis (i.e. in spermiogenesis) were observed and no spermatocytes were found; it seems that in male aphids the germ cells undergo meiosis during larval stages. Germ cells develop within a cyst in full synchrony; however, separate cysts may be at different stages of differentiation (i.e. one cyst may contain young spermatids and the other older spermatids) (Fig. $2 \mathrm{a}, \mathrm{d})$. Usually the cysts with young spermatids occupy the apical part of testicular follicle, whereas the cysts with old spermatids and spermatozoa can be found in the basal part of the testicular follicle (Fig. 2a, b). The testicular follicle wall is built of a layer of extremely elongated epithelial cells standing on a thin basal lamina (Fig. 2b-c). Similarly, the cyst cells are extremely thin; they are slightly broader only in the nuclear region (Fig. 2d). Thin muscle strands are associated with follicle epithelium (Fig. 2c). 


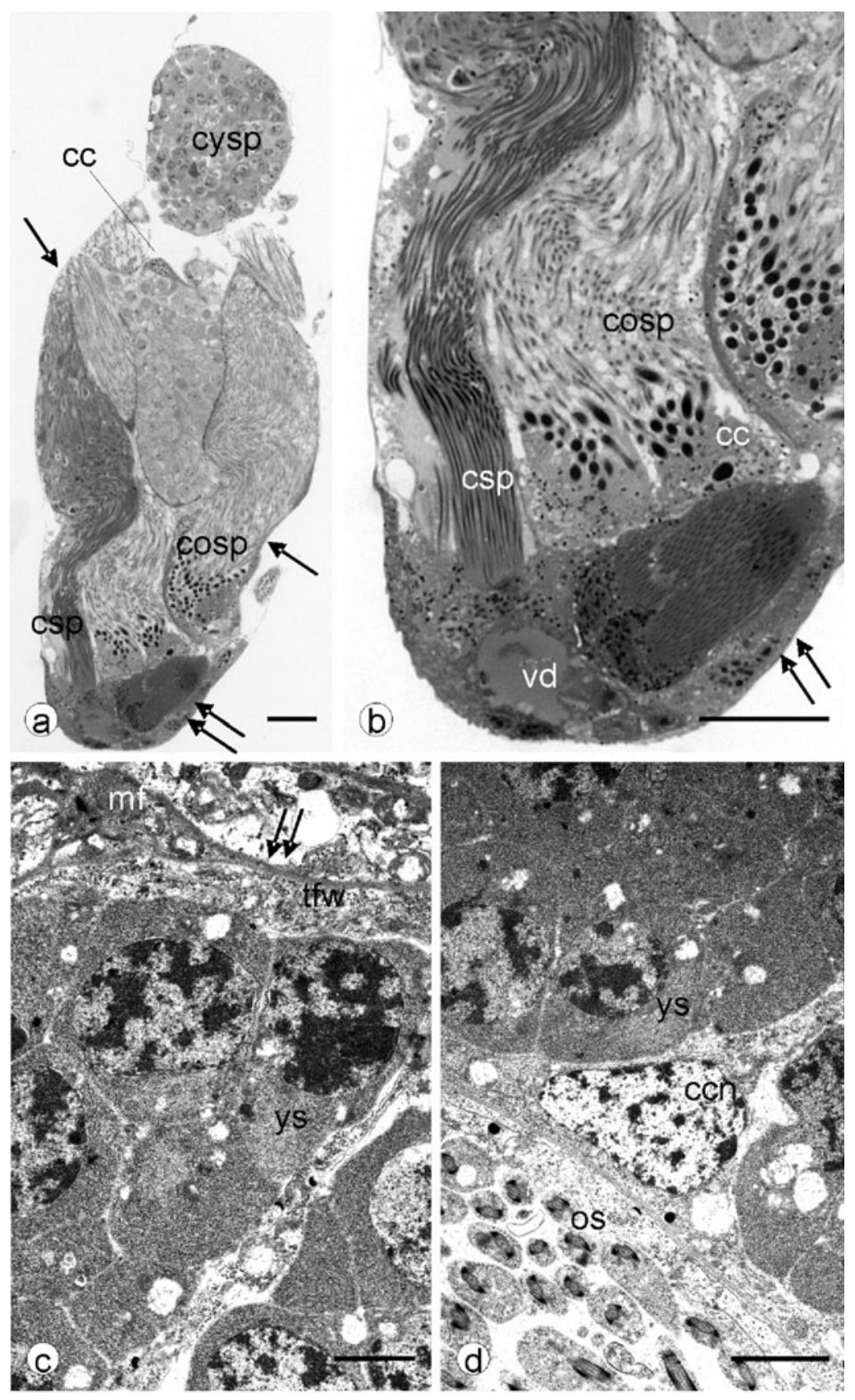

Fig. 2. Details of testicular follicle organization. a, b- semi-thin sections through the follicle. The cysts with germ cells in different stages of spermiogenesis are visible. Arrows point to follicle wall; cc - cyst cell; cysp - cyst with young spermatids; cosp cyst with old spermatids; csp - cyst with spermatozoa; vd - vas deferens. LM, epon section, bars $=20 \mu \mathrm{m}$. c, $\mathrm{d}$ - fragments of cyst ultrastructure. Arrows mark basal lamina of the testicular follicle wall (tfw); ccn - nucleus of the cyst cell; mf - muscle fibres; ys young spermatids; os - older spermatids. Transmission electron microscopy (TEM), bars $=3 \mu \mathrm{m}$.

\section{Vasa deferentia}

Vasa deferentia have a prominent wall composed of two layers (Fig. 3a-d). The outer is formed by thin circular muscle cells (Fig. 3b, c), whereas the inner is built by cubical epithelium of secretory type (Fig. 3a-d). The epithelial cells lie on thin basal lamina (Fig. 3c). Their nuclei are irregular in shape, with prominent spherical nucleoli and clumps of heterochromatin (Fig. 3c, d). Their cytoplasm has well-developed rough endoplasmic reticulum, Golgi complexes and numerous secretory granules (Fig. 3c, d). The granules consist of two kinds of material: electron dense homogeneous substance and electron lucent material usually observed at the granules periphery (Fig. 3c). Similar granules were observed within the cytoplasm of cyst cells bearing spermatozoa in vas deferens lumen (Fig. 3d) and within the cytoplasm of accessory gland cells (see below). The apical plasma membrane of epithelial cells forms short microvilli (Fig. $3 \mathrm{c}, \mathrm{d})$. The apical parts of these cells are connected by cell junctions of zonula adherens and septate junction type (Fig. 3c). Vas deferens lumen is filled with electron dense secretion, in which bunches of spermatozoa, often 

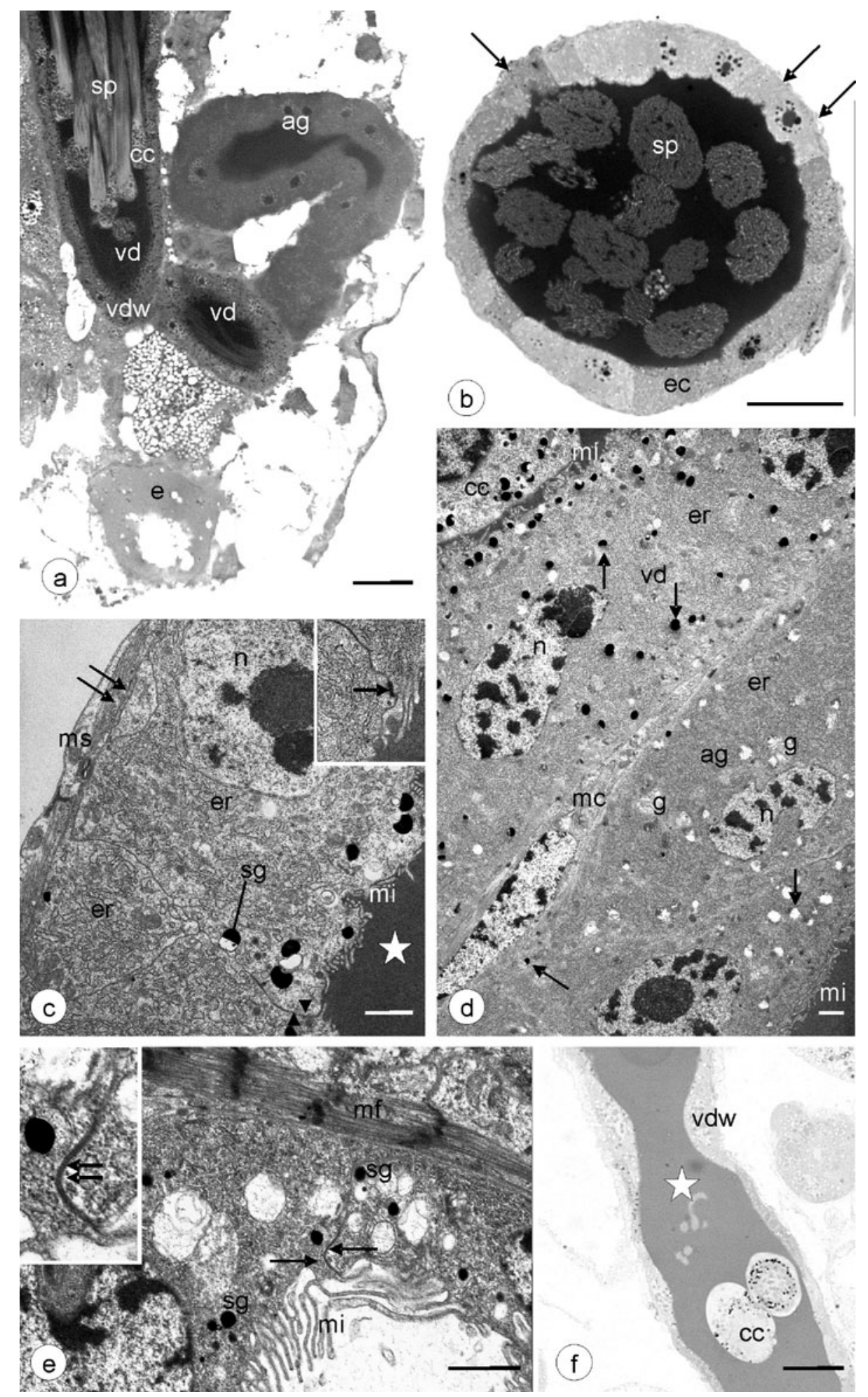

Fig. 3. a - section through vas deferens (vd), accessory gland (ag) and ejaculatory duct (e). Within the vas deferens lumen there are bunches of spermatozoa (sp) joined to cyst cells (cc); vdw - vas deferens wall. LM, epon semi-thin section, bar $=20 \mu \mathrm{m}$. $\mathrm{b}-$ cross section through the vas deferens; arrows mark a thin layer of circular muscle; ec - epithelial cells forming vas deferens wall; $\mathrm{sp}$ - bunches of spermatozoa. LM, epon semi-thin section, bar $=20 \mu \mathrm{m} . \mathrm{c}$ - details of vas deferens structure. Arrows point to extremely thin basal lamina, arrowheads - cell junction of the zonula adherens type; er - endoplasmic reticulum; mi - microvilli; ms - circular muscle; $\mathrm{n}$ - nucleus of epithelial cell forming the vas deferens wall; sg - secretory granules; star - vas deferens lumen. Inset - a higher magnification of zonula adherens (arrow). TEM, bar $=1 \mu \mathrm{m} . \mathrm{d}$ - the walls of vas deferens (vd) and accessory gland (ag) in close contact. Arrows point to secretory granules; cc - cyst cell in vas deferens lumen; er - rough endoplasmic reticulum; $g$ - Golgi complexes; mi - microvilli; mc - muscle cell; $\mathrm{n}$ - nuclei of epithelial cells. TEM, bar $=1 \mu \mathrm{m}$. $\mathrm{e}$ - fragment of the distal end of the ejaculatory duct. Muscle fibres are visible (mf), the epithelial cells contain secretory granules (sg) and are joined by cell junction of septate junction type (arrows). Note long microvilli (mi). Inset - a higher magnification of the septate junction (double arrows). TEM, bar $=1 \mu \mathrm{m}$. f - PAS-stained epon section of vas deferens, note positively stained secretion (star); cc - cyst cells; vdw - vas deferens wall. $\mathrm{LM}, \mathrm{bar}=20 \mu \mathrm{m}$. 
joined to cyst cells, were observed (Fig. 3a, b). The secretion is PAS (Fig. 3f) and BPB positive (not shown).

\section{Accessory glands}

The gland lumen is filled with electron dense substance (Fig. 3a, d), which is, as in the case of vas deferens, PAS and BPB positive (not shown). The accessory gland wall has a similar structure as that of vas deferens. It is also composed of a thin layer of circular muscle cells and cubical epithelium (Fig. 3a, d). The epithelial cells lie on thin basal lamina, their ultrastructure closely resembles that described above for vas deferens wall cells (Fig. 3d). The secretory granules also have the same ultrastructure as that of vas deferens cells. Like in the case of vas deferens epithelial cells, the apical plasma membrane of cells building the accessory gland wall forms short microvilli (Fig. 3d).

\section{Ejaculatory duct}

The ejaculatory duct wall is built of epithelial cells standing on basal lamina and lined with cuticle (Figs 1c, $3 \mathrm{e})$. The cuticle is thin, folded and separated from the cells (Fig. 1c). The cytoplasm of the ejaculatory duct cells contains electron-dense secretory granules (Fig. 3e). The apical plasma membrane forms long microvilli (Fig. 3e). The cells are connected by cell junctions of zonula adherens and septate junction type (Fig. 3e). The lumen of the ejaculatory duct is electron-lucent, filled with flocculent material (Fig. 3e). The muscle fibres do not form a prominent layer, being rather loosely arranged around the ejaculatory duct (Fig. 3a, e).

\section{DISCUSSION}

In general, the structure of the internal reproductive system of $P$. fagi is similar to that of other insects (Chapmann, 2004). The testis follicles contain cysts with developing germ cells. The vasa deferentia, accessory glands and ejaculatory duct are, as in other insects (Chapmann, 2004; Gillot, 1988; Happ, 1984), composed of one layered epithelium standing on a basal lamina. The muscle fibres are also associated with ducts. However, in contrast to other insects, where the structure of the vasa deferentia, accessory glands and ejaculatory ducts may be extremely complex (for details see: Gillot, 1988; Happ, 1984), in the studied species these structures are histologically very simple and have almost identical ultrastructure. They are all built of epithelial cells of secretory type, their cytoplasm contains well-developed rough endoplasmic reticulum, Golgi complexes and numerous small vacuoles with secretion. The histochemical staining shows that the secretion contains proteins and polysaccharides. The apical plasma membrane of these epithelial cells forms microvilli, especially well-developed in the distal end of the ejaculatory duct. The epithelial cells are, as in the case of the reproductive system described in other insects, joined by cell junctions of zonula adherens and septate junction type (Happ, 1984).

The male reproductive system of Aphididae, in comparison with other groups of Hemiptera, is marked by the lack of vesiculae seminalis and random arrangement of spermatids in follicle cysts. In most aphids oligomerisation of the number of testis follicles, from seven (e.g. Lachnus roboris, L. longirostris) to one in each testis (e.g. Pterocallis alni) is observed. This process takes place in almost all the aphid subfamilies examined so far (Chaitophorinae, Calaphidinae, Lachninae, Aphidinae), so that on the species and genera levels it can be used successfully to explain relationships in individual phyletic lines; species with the greater number of follicles are regarded as evolutionarily older (Wojciechowski, 1977). A decrease in the number of testis follicles is also connected with the process of spermatogenesis brought forward to earlier larval stages or even finished during the embryonic life in some species (Blackman, 1987). The polymerisation of testis follicles, which is common among other Hemiptera, is not known in aphids. The independent course of the vasa deferentia along their whole length is considered the plesiomorphic state (e.g. Chaitophorinae); modifications of this plan, which concern mainly the connection between the initial parts of these ducts (the walls cling together distally, connected by distinct bridges and creating a suck-like cave, or the walls between vasa deferentia disappear - Calaphidinae, Saltusaphidinae, Lachninae), are characteristic of phylogeneticly younger forms. Male aphids usually have double accessory glands, which always enter the ejaculatory duct independently and centrally compared to the outlets of vasa deferentia, usually in its apical part. The ejaculatory duct in most species is relatively short, sacklike in shape, its terminal part is connected with the penis.

These characters of the male reproductive system are connected with the mode of reproduction specific to aphids - cyclical parthenogenesis. Males are rare and not numerous (sometimes dwarfish), appear only for a short period of time (in most species only during autumn), and their mating behaviour (many short copulations) requires a certain simplicity in the structure of the reproductive system. Although there are no reports describing the male reproductive system in other species of aphids at the ultrastructural level, we suppose that the histological simplicity is typical of all aphids. However, in some aphids there are additional modifications of the male reproductive system, e.g. Lachninae are characterized by the lack of accessory glands (Wojciechowski, 1977), some representatives of Chaitophorinae or Calaphidinae have a well developed ejaculatory duct (Wieczorek \& Wojciechowski, 2004; Wieczorek, 2006), whereas Anoecia corni has testes connected in their medial part (Wieczorek, 2008). In the case of these aphids, we need a more detailed histological study.

$P$. fagi probably represents the general structural pattern of the male reproductive system of aphids. Moreover, the morphology of this system resembles that known from all the species of Calaphidinae examined so far (i.e. testis follicles arranged in a rosette and strongly elongated, vasa deferentia slightly expanded in their medial part, walls of vasa deferentia clinging together in their basal part, accessory glands strongly elongated, ejaculatory duct reduced - Wieczorek, 2006; Wieczorek \& Świątek, 2007), but 
differ from related Drepanosiphinae and Chaitophorinae (i.e. testis follicles not arranged in a rosette, vasa deferentia independent on the whole length and strongly expanded in their medial part, the walls of vasa deferentia never clinging together in their basal part, accessory glands usually short and ejaculatory duct well defined as a spherical structure with the apical part bulging towards the thorax - Wieczorek \& Wojciechowski, 2004).

In the classification of Aphididae, the genus Phyllaphis was usually placed within Calaphidinae (Callaphididae sensu Borner, 1952, Drepanosiphinae sensu Eastop, 1977, Phyllaphidinae sensu Heie, 1982). According to Quednau \& Remaudière (1994), this genus is closely related to the genera Stegophylla, Diphyllaphis and Machilaphis, and now the subfamily Phyllaphidinae consists only of these four genera. The lack of data on the structure of the male reproductive system in representatives of Stegophylla, Diphyllaphis and Machilaphis makes it impossible at the moment to compare these genera on an anatomical level, which also needs further study.

ACKNOWLEDGEMENTS. The authors would like to thank the Rector of the University of Silesia, Katowice, Poland, for financially supporting this research.

\section{REFERENCES}

BLACKMAN R.L. 1987: Reproduction cytogenetics and development. In Minks A.K. \& Harrewijn P. (eds): Aphids, their Biology, Natural Enemies and Control. Elsevier, Amsterdam, pp. 163-197.

BlackMan R.L. \& EAStop V.F. 1994: Aphids on the World's Trees. An Identification and Information Guide. Cambridge University Press, Cambridge, 986 pp.

Borner C. 1952: Europae Centralis Aphides die Blattlaeuse Mitteleuropas Namen, Synonyme, Wirtspflanzen, Generationszyklen. Mitt Thüring Bot. Ges. 3. Vols 1, 2. Weimar, 488 pp.

Chapmann R.F. 2004: The Insects. Structure and Function. Cambridge University Press, Cambridge, 770 pp.

EASTOP V.F. 1977: Worldwide of aphids as virus vector. In Harris K.F. \& Maramorosch K. (eds): Aphids as Virus Vectors. Academic Press, New York, San Francisco, London, pp. $1-63$.

Gillot C. 1988: Arthropoda - Insecta. In Adiyodi K.G.\& Adiyodi R.G. (eds): Reproductive Biology of Invertebrates. III. Accessory Sex Glands. Wiley \& Sons, Chichester, pp. 319-471.

Głowacka E., Klimaszewski S.M., Szelegiewicz H. \& WojCIECHOWSKI W. 1974: Uber den Bau des mannlichen Fortpflanzungssystems der Aphiden (Homoptera, Aphidoidea). Ann. Univ. Mariae Curie-Sklodowska (Lublin) (C) 29: 133-138.
HAPP G.M. 1984: Structure and development of male accessory glands. In King R.C. \& Akai H. (eds): Insect Ultrastructure. Vol. 2. Plenum Press, New York, pp. 365-396.

HeIE O.E. 1982: The Aphidoidea (Hemiptera) of Fennoscandia and Denmark. II. The Family Drepanosiphidae. Fauna Entomologica Scandinavica. Vol. 11. Sciandinavian Science Press, Klampenborg, $175 \mathrm{pp}$.

IVERSEN T. \& HaRding S. 2007a: Life table parameters affecting the population development of the woolly beech aphid, Phyllaphis fagi L. Entomol. Exp. Appl. 123: 109-117.

IVERSEN T. \& HARDING S. 2007b: Biological and other alternative control methods against the woolly beech aphid Phyllaphis fagi L. on beech Fagus sylvatica seedlings in forest nurseries. J. Pest Sci. 80: 159-166.

Klimaszewski S.M., Szelegiewicz H. \& Wojciechowski W. 1973: Über den Bau des mannlichen Fortpflanzungssystems von Drepanosiphum platanoidis (Schr.) (Homoptera, Aphidoidea). Bull. Acad. Pol. Sci. 10: 671-674.

Nieto Nafria J.M. \& Mier Durante M.P. 1998: Fauna Iberica 11. Hemiptera: Aphididae I. Museo Nacional, Madrid, 425 pp.

PRABUCKI J. 1972: Z badań nad biologią spadziodajnej mszycy Phyllaphis fagi L. (Homoptera). [Studies on honeydew aphid Phyllaphis fagi L. (Homoptera).] Pol. Pis. Entomol. 42: 258-269 [in Polish].

Quednau F.W. \& Remaudière G. 1994: Le genre sud-americain Neuquenaphis E.E. Blanchard, description de deux nouvelles espèces et definition de nouvelles sous-familles d'Aphididae (Homoptera). Bull. Soc. Entomol. Fr. 99: 365-384.

Remaudière G. \& Remaudière M. 1997: Catalogue of the World's Aphididae (Homoptera, Aphidoidea). INRA Editions, Versailles, $473 \mathrm{pp}$.

Stroyan H.L.G. 1977: Homoptera: Aphidoidea: Chaitophoridae and Callaphididae. Handbooks for the Identification of British Insects. Vol II. Part 4(a). Royal Entomological Society of London, London, $130 \mathrm{pp}$.

WIECZOREK K. 2006: Anatomical investigations of the male reproductive system of five species of Calaphidinae (Hemiptera, Aphidoidea). Insect System. Evol. 37: 457-465.

WiECZOREK K. 2008: Structure of the male reproductive system of Anoecia (Anoecia) corni Fabricius, 1775 (Hemiptera, Aphidoidea), a representative of the family Anoeciidae. Acta Zool. 89: 163-167.

WieczoreK K. \& Ś WiąteK P. 2007: Classification of the drepanosiphine aphids (Hemiptera, Aphidoidea: Phyllaphidinae, Calaphidinae, Drepanosiphinae) in the light of the anatomy research. Int. J. Invert. Taxonomy - Genus (Suppl.) 14: 63-65.

Wieczorek K. \& WoJciechowsKi W. 2004: The systematic position of Chaitophorinae (Hemiptera, Aphidoidea) in the light of anatomy research. Insect System. Evol. 35: 317-327.

WoJCIECHOWski W. 1977: Procesy oligomeryzacji w budowie męskiego układu rozrodczego miodownic (Homoptera, Lachnidae). [Oligomerisation processes in the structure of male genitalia in Lachnidae (Homoptera)]. Prace Naukowe UŚl. (Katowice) 3: 140-164 [in Polish].

Received November 28, 2007; revised and accepted January 25, 2008 